\title{
The Path of Financial Institutions to Develop Green Finance to Support the Conversion of New and Old Kinetic Energy in Shandong Province
}

\author{
Sui Jincheng ${ }^{1}$, Liu Jingyun ${ }^{2}$, Zhao Jiaxiu ${ }^{3, *}$ \\ ${ }^{1}$ HENGFENG BANK CO.,LTD., China \\ ${ }^{2}$ United Equatorial Environmental Assessment Co. LTD., China \\ ${ }^{3}$ United Equatorial Environmental Assessment Co. LTD., China
}

\begin{abstract}
Green finance, as an important driving force and support for economic development, has been playing an irreplaceable role since Shandong province began to build comprehensive pilot zones for the conversion of old and new driving forces. In order to further explore the financial institutions to develop green financial support to the realization of the old and the new kinetic energy conversion path, release more potential to help financial institutions and the function, this article system combing the preliminary results of old and new kinetic energy conversion in Shandong province, and the green credit, as a typical example of green finance, its action mechanism were analysed, the result shows that the enterprise's development and mutual restriction relations between green finance. Based on this, this paper puts forward the proposed path for financial institutions to develop green finance to support the transformation of old and new driving forces in Shandong Province.
\end{abstract}

\section{RESEARCH BACKGROUND}

\subsection{Shandong Province promotes the conversion of new and old kinetic energy}

As early as 2015, the term "new and old kinetic energy" was repeatedly mentioned in government documents. Specifically, the conversion of new and old kinetic energy has three meanings. One is to hedge against the weakening of traditional kinetic energy through the increase of new kinetic energy, to accelerate the cultivation of new technologies and new industries, and to find new economic growth points; the other is to innovate through mass entrepreneurship, " "Internet+" and others have created new business formats and new models to transform traditional kinetic energy; third, through the "strategic depth" created by new kinetic energy to gain space for the upgrading of traditional kinetic energy[1]. The contradiction between the supply side and the demand side is improved through the conversion of new and old kinetic energy, or more demand is created through new reforms to improve the economy. After continuous deliberation, in January 2017, the State Council issued the first official document of "New and Old Kinetic Energy Conversion". On March 6, 2017, Premier Li Keqiang hoped that Shandong will continue to take the lead in the conversion of new and old kinetic energy at the two sessions. On January 3, 2018, the State Council formally approved the "General Plan for the Construction of Shandong's New and Old Kinetic Energy Conversion

\footnotetext{
"Corresponding author:zhaojiaxiu0803@163.com
}

Comprehensive Experimental Zone", which marked the construction of Shandong's new and old kinetic energy conversion comprehensive test zone as a national strategy. This is also the first in China to use new and old kinetic energy conversion as the theme. Regional development strategy.

\subsubsection{Clarify key development industries}

In 2018, Shandong Province issued the "Implementation Plan for the Conversion of New and Old Kinetic Energy in Shandong Province", taking the cultivation and growth of "top ten" industries as an important focus of the conversion of new and old kinetic energy, and accelerating the promotion of a new generation of information technology The five major emerging industries have accelerated their rise, the transformation and upgrading of the five traditional industries, such as the chemical industry, and efforts to build a modern economic system. The specific content is shown in Table 1. 
Table 1. Key development areas of the "Top Ten" industries in the conversion of new and old kinetic energy in Shandong

\section{Province}

\begin{tabular}{|c|c|}
\hline Industry & Important area \\
\hline $\begin{array}{l}\text { A new } \\
\text { generation } \\
\text { of } \\
\text { information } \\
\text { technology }\end{array}$ & $\begin{array}{l}\text { Microelectronics, sensors, virtual reality, } \\
\text { new displays, high-end storage, artificial } \\
\text { intelligence, basic software, quantum } \\
\text { computing, cloud computing, big data, smart } \\
\text { cities, information security, geographic } \\
\text { information, "Internet +" ecological } \\
\text { construction }\end{array}$ \\
\hline $\begin{array}{l}\text { High-end } \\
\text { equipment }\end{array}$ & $\begin{array}{l}\text { Intelligent manufacturing, rail transit, marine } \\
\text { engineering equipment, construction } \\
\text { machinery, agricultural machinery } \\
\text { equipment, power machinery, equipment } \\
\text { core parts, general aircraft manufacturing. }\end{array}$ \\
\hline $\begin{array}{l}\text { New energy } \\
\text { and new } \\
\text { materials }\end{array}$ & $\begin{array}{l}\text { New energy power batteries, electronic } \\
\text { control systems, hydrogen fuel cell } \\
\text { industrialization, new energy vehicle } \\
\text { manufacturing, new energy vehicle time- } \\
\text { sharing leasing, energy storage battery } \\
\text { charging and replacement applications; } \\
\text { Distributed energy, renewable energy } \\
\text { development, combustible ice development } \\
\text { and application; } \\
\text { Carbon fibres, graphene, bio-based } \\
\text { materials, functional crystals. }\end{array}$ \\
\hline $\begin{array}{l}\text { Smart } \\
\text { Marine }\end{array}$ & $\begin{array}{l}\text { Marine granaries, marine pastures, deep-sea } \\
\text { fishery, marine biomedicine, high-tech ships, } \\
\text { marine finance, marine information, marine } \\
\text { commerce, and marine desalination. }\end{array}$ \\
\hline $\begin{array}{l}\text { Medical } \\
\text { support } \\
\text { health }\end{array}$ & $\begin{array}{l}\text { Biomedicine, marine medicine, modern } \\
\text { Chinese medicine, biomedical engineering, } \\
\text { high-end medical equipment; } \\
\text { Mobile medical care, remote diagnosis and } \\
\text { treatment, smart medical care, smart } \\
\text { hospitals, and medical pension complexes. }\end{array}$ \\
\hline $\begin{array}{l}\text { Green } \\
\text { chemical }\end{array}$ & $\begin{array}{l}\text { Aromatics, ethylene, petrochemical deep } \\
\text { processing, biochemical industry, new coal } \\
\text { chemical industry, fine salt chemical } \\
\text { industry. }\end{array}$ \\
\hline $\begin{array}{l}\text { Modern and } \\
\text { efficient } \\
\text { agriculture }\end{array}$ & $\begin{array}{l}\text { The integration of agricultural three } \\
\text { industries, smart agriculture, customized } \\
\text { agriculture, experience agriculture, rural e- } \\
\text { commerce, smart cloud farm, cold chain } \\
\text { logistics, deep processing of agricultural } \\
\text { products, deep processing of seafood, the } \\
\text { construction of the comprehensive pilot area } \\
\text { for the development of Weifang agriculture, } \\
\text { and the construction of the Yellow Triangle } \\
\text { agricultural high area. }\end{array}$ \\
\hline $\begin{array}{l}\text { Cultural and } \\
\text { creative }\end{array}$ & $\begin{array}{l}\text { Qufu traditional culture construction, Qi } \\
\text { culture inheritance innovation, Grand Canal } \\
\text { culture, Mozi culture, Luban craftsman } \\
\text { spirit; } \\
\text { Creative design services, major creative } \\
\text { design platforms, film and television culture, } \\
\text { foreign cultural trade. }\end{array}$ \\
\hline $\begin{array}{c}\text { Boutique } \\
\text { tourism }\end{array}$ & $\begin{array}{l}\text { High-quality tourism projects, low-altitude } \\
\text { flights, tourism performing arts, tourism and } \\
\text { leisure, sports and fitness, cruise tourism. }\end{array}$ \\
\hline $\begin{array}{l}\text { Modern } \\
\text { financial }\end{array}$ & $\begin{array}{l}\text { Inclusive finance, regional financial trading } \\
\text { market, Internet finance. }\end{array}$ \\
\hline
\end{tabular}

Focusing on the "Top Ten" industries, Shandong Province has successively issued more than 500 supporting policy documents in terms of finance, taxation, finance, and talent support. In July 2019, the 13th meeting of the Standing Committee of the 13th People's Congress of Shandong Province passed the "Shandong Province New and Old Kinetic Energy Conversion Promotion Regulations". This is the country's first local government regulation to promote high-quality development with the theme of the conversion of new and old kinetic energy. Since 2020, although the pace of conversion of new and old kinetic energy has been affected to some extent by the Covid-19, the overall development trend is stable and improving. The expanded meeting of the leading group for the construction of the new and old kinetic energy conversion comprehensive experimental zone in Shandong Province reviewed and approved the "Key Points for the Construction of the New and Old Kinetic Energy Conversion Comprehensive Experimental Zone in Shandong Province in 2020", and continued to put forward 24 items in terms of cultivating the "top ten" industrial clusters and enhancing scientific and technological innovation capabilities. The tasks and measures have drawn a road map for this year's conversion of new and old kinetic energy in Shandong.

\subsubsection{Specify the direction of green finance support}

In the process of transforming old kinetic energy into new kinetic energy, green-related industries represented by the new generation of information technology industry, new energy and new materials, and smart marine industries are key development industries [2]. The development process will generate a large amount of capital demand, especially for private information technology small, medium and micro enterprises. When encountering financial difficulties, due to the characteristics of light assets, high growth, high risk, and low return, they almost Unable to obtain financing from the bank. In addition, many green projects have short construction periods, high investment intensity, and urgent capital needs. Financing channels have become an important factor restricting their development and growth [3]. To this end, Shandong Province has given full play to the power of green finance and issued the "Opinions on Further Promoting the Expedited Investment of Shandong Province's New and Old Kinetic Energy Conversion Funds" , while establishing the old and new kinetic energy conversion funds, and proposed reforms Fund management system, lower the threshold of fund establishment, improve the efficiency of fund use, optimize the environment for fund development, promote the development of financial resources, and help the "top ten" enterprises to develop and grow. In 2020, the Jinan Branch of the People's Bank of China will cooperate with the Local Financial Supervision Bureau of Shandong Province, the Provincial Development and Reform Commission, the Provincial Department of Industry and Information Technology, the Provincial Department of Finance, the Provincial Department of Ecological Environment, the Provincial Department of Housing and Urban-Rural Development, the Shandong Banking and Insurance Regulatory Bureau, and the Shandong Securities Regulatory Bureau. The department formulated and issued the "Implementation Opinions on the Development of Green Financial Services 
Ecological Civilization Construction and High-quality Green Development", planned and designed the construction of a green financial system at the provincial level, and further strengthened the policy basis and institutional guarantees for the development of green finance in the province.

Up to now, the province has established a total of 545 new and old kinetic energy conversion funds, with a subscribed scale of 737.1 billion yuan, 1977 investment projects, realizing fund investment of 203.6 billion yuan, driving other financial and social capital investment Full coverage of "strong" industries. In terms of promoting the development of agglomeration of financial resources, take Jinan's new and old kinetic energy conversion pilot area as an example, through the organization of multiple bankgovernment docking seminars to coordinate and solve related issues such as location selection and taxation, and accelerate the landing of financial institutions. Up to now, Jinan's new and old kinetic energy conversion pilot area currently has 2 comprehensive bank branches and 23 bank outlets in total, and 5 financial institutions are in the stage of preparation and site selection. There are 6 fund management institutions and 30 registered funds, with a total fund size of 25.7 billion.

\subsubsection{Preliminary development results}

Shandong Province has achieved outstanding results since becoming a comprehensive experimental zone for the conversion of new and old kinetic energy. In 2018, Shandong Province reduced its crude steel production capacity by 3.55 million tons, pig iron production capacity by 600,000 tons, and coal production capacity by 4.95 million tons. The "Four New" economy represented by new technologies, new industries, new formats, and new models developed rapidly. Newly registered market entities were 1.681 million, a year-on-year increase of $12.3 \%$. Among them, newly registered "Four New" economic enterprises increased by $31.0 \%$; The output value of high-tech industries accounted for $36.9 \%$ of the industries above designated size; the added value of the "top ten" industries such as the new generation of information technology manufacturing, new energy, new materials, and high-end equipment increased by $6.7 \%$, $6.0 \%$, and $5.5 \%$, respectively $1.5,0.8$, and 0.3 percentage points in industries above designated size; the output of high-tech products such as industrial robots, urban rail vehicles, and servers increased by $71.5 \%, 20.5 \%$, and $76.3 \%$, respectively; software business revenue was 502.81 billion yuan, an increase of $14.9 \%$; software business exports 1.78 billion US dollars, an increase of $11.3 \%$. In 2019, investment in high energy-consuming industries in Shandong dropped by $21.9 \%$ year-on-year, and the investment in the "four new" economy accounted for $44.8 \%$, an increase of 0.9 percentage points over the previous year; the added value of the "four new" economy accounted for $28 \%$ of the GDP; The output value of hightech industries accounted for $40.1 \%$ of industries above designated size, an increase of 3.2 percentage points over the previous year [4-5].

\subsection{Development status of green finance in China}

Green finance refers to economic activities that support environmental improvement, response to climate change, and resource conservation and efficient use, that is, investment and financing, project operations, risk management, etc. for projects in the fields of environmental protection, energy conservation, clean energy, green transportation, and green buildings Financial services. Since the 18th National Congress of the Communist Party of China, the Party Central Committee and the State Council have promoted the development of green finance to the height of the national strategy. The national "Overall Plan for Ecological Civilization System Reform" and the "Thirteenth FiveYear Plan" outline clearly proposed "establishing a green financial system." In August 2016, the seven ministries and commissions jointly issued the "Guiding Opinions on Building a Green Financial System", which clarified the definition of green finance in China, and proposed eight major measures including vigorously developing green credit, promoting the securities market to support green investment, and establishing green development funds. It marks the establishment of a top-level framework system for green finance in China, and China has become the first country in the world to establish a relatively complete green finance policy system.

\subsubsection{Overview of the development of green bonds}

In early 2016, China's green bond market was officially launched. Driven by both regulatory policies and market demand, the scale of green bond issuance maintained rapid growth. In the whole year, a total of 49 domestic labelled RMB green bonds were issued, with a scale of 198.53 billion yuan; a total of 4 domestic labelled green assetbacked securities were issued with a scale of 6.70 billion yuan. In 2019, China issued a total of 192 green bonds, with a scale of 280.344 billion yuan. The number of issuance periods and issuance scale increased by $48.84 \%$ and $26.94 \%$ respectively over the previous year. The new green bond issuance involved 121 issuers, an increase over the previous year. $37.50 \%, 90$ of which are new issuers in 2019. The market participants of green bonds are increasing, as shown in Table 2.

Table 2. China's green bond issuance (excluding asset-backed securities) from 2016 to 2019

\begin{tabular}{|l|c|c|c|c|}
\hline Project & $\mathbf{2 0 1 6}$ & $\mathbf{2 0 1 7}$ & $\mathbf{2 0 1 8}$ & $\mathbf{2 0 1 9}$ \\
\hline $\begin{array}{l}\text { Issue number } \\
\text { (period) }\end{array}$ & 49 & 104 & 111 & 163 \\
\hline Number of issuers & 29 & 68 & 88 & 121 \\
\hline $\begin{array}{l}\text { Issue size(100 } \\
\text { million yuan) }\end{array}$ & $\begin{array}{c}1985 . \\
3\end{array}$ & $\begin{array}{c}1908 . \\
75\end{array}$ & $\begin{array}{c}2067 . \\
19\end{array}$ & $\begin{array}{c}2439 . \\
87\end{array}$ \\
\hline $\begin{array}{l}\text { Average issuance } \\
\text { period (years) }\end{array}$ & 4.35 & 4.34 & 3.87 & 4.55 \\
\hline
\end{tabular}

Note: The average issuance period is the weighted average of the issuance period of all green bonds (excluding perpetual bonds) based on the issuance scale.

Source: Lianhe Credit COS System

\subsubsection{Overview of green credit development}

On July 12, 2007, the State Environmental Protection 
Administration, the People's Bank of China and the former China Banking Regulatory Commission jointly formulated the "Opinions on Implementing Environmental Protection Policies and Regulations to Prevent Credit Risks", stipulating that banks should implement relevant national systems and optimize them reasonably Improving the credit structure, effectively avoiding credit risks, China's green credit development started from this, and then China's banking industry began to actively respond. In 2012, the China Banking Regulatory Commission issued the "Green Credit Guidelines", which clearly stated that "a comprehensive evaluation of the green credit effectiveness of banking financial institutions, and the evaluation results as the supervision of banking financial institutions in accordance with relevant laws and regulations" An important basis for rating, institution access, business access, and evaluation of senior management's performance." In 2013, the China Banking Regulatory Commission formulated the "Green Credit Statistics System", requiring banks to conduct statistics on loans to enterprises with major environmental and safety risks, as well as loans to energy conservation and environmental protection projects and services. In June 2014, the China Banking Regulatory Commission further issued the "Key Evaluation Indicators for the Implementation of Green Credit" as the basis and basis for green bank ratings. On January 19, 2015, the China Banking Regulatory Commission and the National Development and Reform Commission jointly issued the "Energy Efficiency Credit Guidelines" in Beijing. At the beginning of the same year, the China Banking Regulatory Commission issued the "Notice of the General Office of the China Banking Regulatory Commission on Issuing Two Templates for Self-evaluation of Green Credit Implementation". In 2015 and 2016, the green credit selfevaluation work of 21 major banks across the country was carried out twice. In 2018, the People's Bank of China issued the "Notice on Establishing a Special Statistical System for Green Loans", formally establishing a green credit statistical system, standardizing the green credit data reporting mechanism, and providing support for the development and promotion of green credit development. For reference. As China's banking financial institutions continue to increase their investment and support for green credit funds and the continuous implementation of the financing constraints of the "two highs and one overcapacity" industry, China's green credit products have achieved relatively good results in exploration and innovation, Between June 2013 and December 2019, the green credit balance of 21 major banks in China has grown steadily from 4.85 trillion yuan to 10.22 trillion yuan, with an average annual growth rate of more than $10 \%$. In 2019 , the green credit scale of many banks exceeded 100 billion yuan. Among them, the green credit scale of Industrial and Commercial Bank, Agricultural Bank, and China Construction Bank exceeded one trillion yuan, with an average annual growth rate of about $10 \%$.

Table 3. 2013-2019 China's green credit balance

\begin{tabular}{|c|c|c|c|}
\hline Time & $\begin{array}{c}\text { Green credit } \\
\text { balance } \\
(100 \text { million } \\
\text { yuan) }\end{array}$ & Time & $\begin{array}{c}\text { Green credit } \\
\text { balance } \\
(100 \text { million } \\
\text { yuan })\end{array}$ \\
\hline
\end{tabular}

\begin{tabular}{|c|c|c|c|}
\hline $\begin{array}{c}\text { the first half } \\
\text { of } 2013\end{array}$ & 48526.84 & $\begin{array}{c}\text { the first half } \\
\text { of } 2016\end{array}$ & 72635.29 \\
\hline End of 2013 & 51983.09 & End of 2016 & 75046.87 \\
\hline $\begin{array}{c}\text { the first half } \\
\text { of } 2014\end{array}$ & 57217.26 & $\begin{array}{c}\text { the first half } \\
\text { of } 2017\end{array}$ & 82956.63 \\
\hline End of 2014 & 44363.86 & End of 2017 & $\approx 85,300$ \\
\hline $\begin{array}{c}\text { the first half } \\
\text { of } 2015\end{array}$ & 66361.33 & End of 2018 & 96,600 \\
\hline End of 2015 & 70066.13 & End of 2019 & $>100,000$ \\
\hline
\end{tabular}

Data source: Official website of China Banking and Insurance Regulatory Commission

\subsubsection{Overview of the pilot zone for green finance reform and innovation}

In 2017, the executive meeting of the State Council voted and approved the overall plan for the green finance reform and innovation pilot zone in five provinces, namely Zhejiang Province, Guangdong Province, Xinjiang Uygur Autonomous Region, Guizhou Province and Jiangxi Province. In 2019, the State Council officially approved the establishment of a pilot zone for green finance reform and innovation in Lanzhou New District. Since then, China's green finance has entered a new stage where the "top-down" top-level design and the "bottom-up" exploration are combined. At the top-level design level, the nine major pilot zones have all made overall plans for the regional green finance reform and innovation pilot zones, and issued green finance innovation reform rules adapted to their own regional economic and financial development. The implementation rules mainly include the development positioning of the pilot zone and the division of tasks among various departments. For example, Guangdong Province has formulated and issued detailed implementation rules or task division tables at the three levels of province, city, and district. Huzhou City issued several policy opinions on the construction of green finance reform and innovation pilot zone: establishing special funds for green finance, using incentives, subsidies, compensation and other means to mobilize the enthusiasm and subjective initiative of financial institutions.

In terms of the construction of the green financial system, since 2017 , the first batch of five green financial reform and innovation pilot zones have conducted pilot trials in green financial standard identification, green financial statistics and monitoring mechanisms, and green credit information system construction. In the construction of green finance standards, Zhejiang Huzhou, Jiangxi Ganjiang New Area, Guangdong, Guizhou, and Xinjiang Uygur Autonomous Region have all introduced local green finance standards related policies. For example, the Xinjiang Uygur Autonomous Region has established a green project library management system, taking the construction of green projects as the starting point, and unifying green project support standards. In addition, Zhejiang Huzhou has also established relevant green standards or evaluation requirements from the perspective 
of franchised institutions, such as banks, such as the "Green Bank Evaluation Standards" and the "Banking Industry Green Finance Franchised Institutions Construction Standards". In addition, the pilot zone government has played an active role in guiding the innovation of green financial services. By guiding the establishment of green industry funds and risk compensation mechanisms, financial institutions have dispelled the worries of green financial investment. For example, Huzhou City, Zhejiang Province established a government policy financing to guarantee company with a registered capital of 170 million yuan, giving priority to supporting green small and micro enterprises, and Guizhou Province established five green companies including the Big Data Industry Fund, the Energy Conservation and Low Carbon Industry Investment Fund, and the Guizhou Green Development Fund. The fund has realized the soundness of the green financial infrastructure. Up to now, all the nine pilot zones have established green banking institutions, and the total number of green finance business units or institutions has reached 187.

\section{THE ROLE OF GREEN FINANCE IN THE CONVERSION OF NEW AND OLD MOMENTUM}

Shandong Province implements the conversion of new and old kinetic energy with the goal of cultivating and expanding emerging industries, transforming and upgrading traditional industries, and eliminating outdated production capacity, so as to completely change the resource-based and heavy-duty industrial structure of the province with low industrial levels, poor quality and efficiency, and heavy pollution emissions. To achieve sustainable high-quality development. Energy conservation, emission reduction, and green development are important elements of the conversion of new and old kinetic energy. Among the "top ten" industries, many projects such as new energy and new materials, smart marine industry, and modern high-efficiency agriculture belong to the category of green industries and cannot be separated from green finance. Strong support.

In 2018, the credit line of Shandong (excluding Qingdao) banking financial institutions to the "top ten" industries reached 1054.76 billion yuan, an increase of 70.86 billion yuan from the beginning of the year; the total credit amount was 778.96 billion yuan, an increase of 67.46 billion yuan from the beginning of the year; the loan balance was 5651.8 Billion yuan, an increase of 47.67 billion yuan from the beginning of the year. Among them, the credit line for key projects included in the "Overall Plan for the Construction of the Comprehensive Experimental Zone for the Conversion of New and Old Kinetic Energy in Shandong" has reached 512.08 billion yuan, with a total credit of 292.1 billion yuan and a loan balance of 165.26 billion yuan, an annual increase of 102.85\%. In 2019, Shandong Province (excluding Qingdao), the banking financial institutions of Shandong Province (excluding Qingdao), the conversion of the "top ten" industry and infrastructure credit lines reached $1,694.309$ billion yuan, the total credit used was $1,055.902$ billion yuan, and the loan balance was 744.751 billion yuan; credit lines for key projects It reached 778.795 billion yuan, the total credit amount was 367.667 billion yuan, and the loan balance was 205.206 billion yuan.

In addition to green credit, Shandong Province is also continuing to make efforts in the field of green bonds. In 2016, Bank of Qingdao was approved for the country's first city commercial bank to issue green financial bonds, with an initial issuance of 8 billion yuan, and all raised funds were invested in green fields. In 2017, Qingdao Rural Commercial Bank and Yantai Bank were respectively approved for the issuance of green financial bonds. Currently, the two banks have a total of RMB 3 billion and RMB 3.58 billion respectively. In 2018, Weihai City Commercial Bank and Qilu Bank also obtained issuance qualifications, with the initial issuance scale of 2.5 billion yuan and 3 billion yuan respectively. Innovating the green bill rediscount through train system, with a total of 1.56 billion yuan invested, and actively guiding financial institutions to explore special green credit products such as solid waste loans, contract energy management financing, and renewable energy enterprise accounts receivable pledge loans. At the same time, give full play to the role of green funds to support enterprises to go public. Take Alte Automobile Co., Ltd., which is the first share of the domestic auto-designed GEM board, as an example. In November 2016, Shandong Provincial New and Old Kinetic Energy Conversion Fund invested 22.35 million yuan in Alte Automobile; in March 2017, Shandong Provincial New and Old Kinetic Energy Conversion Fund It reinvested 24.32 million yuan in Alt Auto to fully support the development of the project enterprise. On the basis of increasing financial support, the fund management team also gave full play to its valueadded service capabilities to assist companies in comprehensively sorting out and solving the obstacles to listing, helping companies to speed up the listing process. On March 27, 2020, Alte Automotive Technology Co., Ltd. The company (stock code: 300825) was officially listed on the Growth Enterprise Market of the Shenzhen Stock Exchange. At present, among the projects invested by the Shandong Provincial Government Guiding Fund to participate in the fund, companies such as Suotong Development, Jingjin Environmental Protection, Rike Chemical, and Jin Hyundai have successfully achieved IPOs. In addition, there are also Shanda Diwei, Langchaoyun, and Han Duyi. A large number of highquality companies, including She, have launched listing plans [6]. 


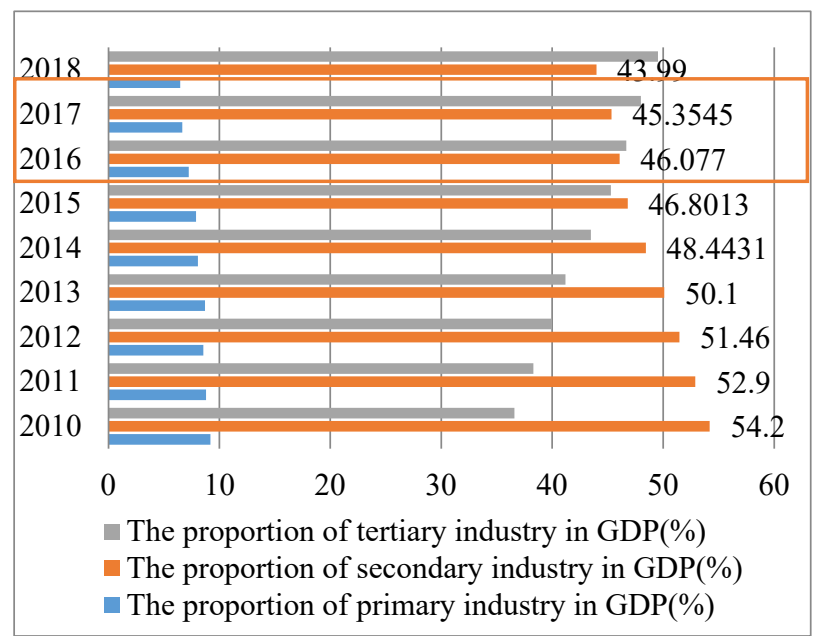

Figure 1 .Changes in the proportion of the primary, secondary and tertiary industries in Shandong Province from 2010 to 2018 Data source: CSMAR database

With the joint efforts of all parties, Shandong's industries are constantly upgrading. As can be seen from Figure 3, the proportion of the secondary industry in the GDP of Shandong Province is declining, and the proportion of the tertiary industry in the GDP is rising, and the proportion of the two is almost the same in 2016. After 2016, especially after Shandong Province has become a comprehensive reform pilot zone for the conversion of new and old kinetic energy, the gap between the two is increasing. Entering 2020, Shandong Province's green finance will continue to make efforts in the conversion of new and old momentum. As of the end of August, Shandong Province has issued a total of 7.792 billion yuan of special bonds for the conversion of new and old kinetic energy in Jinan in 2020 to support the construction of 20 key projects in the region. In August, the 9 departments of Shandong Province issued the "Implementation Opinions on the Development of Green Financial Services Ecological Civilization Construction and High-quality Green Development", aiming at establishing a green financial system, boosting high-quality development, and promoting the construction of ecological civilization. Vigorously develop green credit, use the securities market to support green investment, support the development of green guarantees, establish a green development fund, develop green insurance, build a green financial element trading market, support the development of green finance reform and innovation in various places, build a sound green financial organization system, and establish a sound 31 specific measures were proposed in 11 aspects including green financial infrastructure, prevention and control of green financial risks, and safeguard measures. With the attention and efforts of all parties, the potential of Shandong Province's green finance to support the conversion of new and old kinetic energy will be further released [7].

\section{SUMMARY : GREEN FINANCE SUPPORTS THE CONVERSION PATH OF NEW AND OLD KINETIC ENERGY IN SHANDONG PROVINCE}

Path 1: Clarify the scope and direction of key support for green investment

A clear investment scope and investment direction are the prerequisite and basis for financial institutions to innovate financial instruments. This requires that, one is to formulate standards for the scope of support in accordance with local conditions. At present, the current domestic green finance standards mainly include the green industry catalog, green credit standards and green bond standards. In December 2015, the People's Bank of China issued the "Catalogue of Green Bond Support Projects (2015 Edition)". In the same month, the National Development and Reform Commission issued the "Green Bond Issuance Guidelines". In February 2019, the National Development and Reform Commission, the People's Bank of China and other seven ministries and commissions jointly issued the "Green Industry Guidance Catalog (2019 Edition)". The content of several major standards is different, and the scope of application is also different. The "Green Bond Support Project Catalog (2015 Edition)" is applicable to green financial bonds, green corporate bonds, and green debts in charge of the People's Bank of China, the China Securities Regulatory Commission, and the Interbank Market Dealers Association. Green bond products such as financing instruments and green asset-backed securities. The National Development and Reform Commission's "Green Bond Issuance Guidelines" only applies to green corporate bonds in charge of the National Development and Reform Commission; the green credit standards mainly refer to the People's Bank of China's "Notice on Establishing a Special Statistical System for Green Loans" and the China Banking and Insurance Regulatory Commission's "Notice on the Work Related to the Green Financing Statistical System". In the specific work process, financial institutions should strengthen systematic learning, clarify the boundaries and content of each standard, combine green finance with the conversion of old and new kinetic energy, establish its special green support list according to local conditions, and support to meet the green financial standards and the new and old kinetic energy of Shandong Province Convert the required green projects. The second is to strengthen communication and coordination with financial regulatory authorities. After the "Guiding Opinions on Building a Green Financial System" of seven ministries including the People's Bank of China was formulated and implemented in 2016, the Jinan Branch of the People's Bank of China immediately forwarded and put forward clear requirements throughout its jurisdiction to fully initiate the construction of the province's green financial system. Especially since 2018, in order to cooperate with the promotion of the transformation of old and new kinetic energy and the high-quality economic development of the province, Jinan Branch has continued to vigorously carry out green finance development actions. With the joint efforts of relevant departments, Shandong Province has achieved remarkable results in the development of green finance [8]. Financial institutions should take the initiative to strengthen communication and coordination with financial regulatory authorities, learn to understand local regulatory policy guidance, and actively innovate and 
practice product tools. The third is to actively participate in the local green finance reform and innovation pilot zone. The construction of the local green finance reform and innovation pilot in Shandong Province is a new attempt to promote green finance and is conducive to the green transformation and upgrading of the economy. At the same time, the exploration of local regions is more focused and targeted, and relevant innovation policies are easier to implement. With the increasingly close interaction between the old and new kinetic energy conversion and green finance in Shandong Province, financial institutions should actively participate in the reform and innovation of local green finance, and contribute their own strength to the old and new kinetic energy conversion in Shandong Province [9].

\section{Path 2: Continue to innovate green financial products}

Although China's various green financial products are becoming more abundant, in terms of scale, green credit is still the leading factor, and financial institutions still need to actively develop and innovate a diversified green financial product system [10]. In view of the current policy and market development, this article puts forward the following product innovation suggestions. One is to actively develop blue bonds. The blue bond is an innovative marine conservation financing tool. The funds raised are dedicated to marine-friendly projects, including all projects related to the restoration, protection or maintenance of the diversity, core functions and overall health of the marine ecosystem, as well as enhancing the adaptive capacity of coastal areas This is particularly applicable to Shandong Province. In September 2020, Bank of China successfully issued the first blue bond of Chinese-funded and global commercial institutions overseas. This issue of bonds includes two varieties with a three-year maturity of USD 500 million and a two-year maturity of RMB 3 billion, respectively issued by Bank of China Paris Branch and Macau Branch. In November, China's first domestic blue bond Qingdao Water Group Co., Ltd.'s 2020 first phase of green medium-term notes (blue bonds) was successfully issued, and 300 million yuan of blue bond funds will be used for the expansion project of Qingdao Baifa desalination plant The construction of the project is of great significance for increasing the strategic reserve of freshwater resources and building a blue circular economy industrial chain, and provides new ways and new ideas for domestic enterprises to participate in the development of the marine economy and the utilization of marine resources. On the basis of existing successful cases, financial institutions in Shandong Province can continue to innovate, make continuous efforts, and continue to explore blue bond landing projects. The second is to promote the development of carbon finance. At the United Nations General Assembly held on September 22, 2020, President $\mathrm{Xi}$ Jinping said: "China will increase its nationally determined contributions, adopt more powerful policies and measures, and strive to reach the peak of carbon dioxide emissions by 2030 , and strive to achieve carbon emissions by 2060 . Neutralization." The proposal of this goal once again pushes carbon finance to the forefront of development. Carbon finance includes investment and financing of low-carbon projects, carbon emission rights and derivatives trading, carbon funds, carbon insurance and other financial activities, providing commercial banks with space to expand new businesses and increase green finance revenue. The international banking industry has achieved rapid development in emerging areas such as carbon finance. For example, Standard Chartered Bank and HSBC have made a lot of innovations around carbon emission reduction rights. All major commercial banks in China must actively participate in carbon finance activities, provide financial services such as investment and wealth management, financial management, and financial leasing for the development of green and environmentally friendly enterprises, and actively carry out financing based on carbon emission reduction projects, carbon emission rights futures trading and other businesses; Establish a special institution to speed up the development of a risk aversion system in accordance with its own characteristics and the development direction of green finance, in accordance with the international carbon financial product transaction scale, service level and risk rating and other indicators, so as to achieve the internationalization of China's green finance development as soon as possible [11]. The third is to continue to innovate green credit products. At present, green investment in China's banking industry is mostly based on green credit. From the perspective of scale, green credit accounts for more than $90 \%$ of the total scale of green investment in the banking industry. Therefore, on the one hand, it is necessary to encourage banking institutions to actively issue green financial bonds to expand the sources of green credit funds On the other hand, it is necessary to continue to carry out innovative research on green credit products. Special green credit collections can be used as the source of funds to issue inter-bank green ABS and raise funds. The funds can continue to be used to issue a new batch of special green credits, support green assets that meet the list of special green credit support, and further increase the rate of new kinetic energy green assets.

\section{Path 3: Promote the efficient delivery of green financial products One is to introduce ESG corporate performance evaluation to lower the threshold for product restrictions}

Enterprise ESG (Environmental, Social and Government: Environmental, Social and Government) performance evaluation has become an important basis for evaluating sustainable and green development of enterprises in the current domestic and foreign capital markets. According to the "2019 Research Report on ESG Evaluation System of Chinese Listed Companies" released by the China Fund Industry Association in May this year, ESG has become a mainstream investment philosophy and investment strategy in the international asset management industry. When conducting specific business, financial institutions should also introduce ESG corporate performance evaluation in the review of loans issued by enterprises, 
especially private small and micro enterprises, pay attention to the review of the first repayment source, and abandon the old concept of only accepting mortgage guarantee, On the basis of strengthening risk identification and judgment and improving the level of risk management and control, continuously lowering the entry threshold of private enterprise credit. The second is to improve assessment, incentives and accountability methods. In terms of performance appraisal of grassroots institutions, banking institutions should focus on supporting private enterprises and guide grassroots banks to increase credit investment in private enterprises through the performance appraisal "baton". At the same time, in response to the current practical difficulties faced by private and small, medium and micro enterprises, relevant regulations on due diligence and exemption should be revised and improved in a timely manner to make it more in line with the reality and more scientific and reasonable. It is necessary to plug accountability loopholes, avoid deviation from reality, and eliminate grassroots customers. The manager's excessive worry about loan accountability, through assessment and incentives and due diligence, let him dare to lend and willing to lend [12]. The third is to improve product launch efficiency. Due to the large number of examination and approval procedures when financial products are launched, the time is long and the efficiency is low. The financing time of enterprises is extended. For small and micro enterprises, the consequences of extending financing time are often fatal. Therefore, it is necessary to improve service levels and effects, continuously improve the efficiency of green financial products, and simplify the credit process. For major customers of special green credit, banks can provide direct financing financial services, while assisting companies that meet the requirements to issue green bond products such as green bonds and green asset securitization, so as to realize the multi-channel support of green finance for new momentum. At the same time, decentralization of approval authority. At present, some banks have many steps and complicated procedures for loans to enterprises, and the loan approval authority is mostly concentrated in the superior bank, which affects the enthusiasm of the grassroots bank to lend. Efforts should be made to simplify the process, delegate loan approval powers, and strengthen the equalization of powers and responsibilities, so as to mobilize grassroots banks' enthusiasm for private enterprise credit.

\section{REFERENCES}

1. Huang Zhenhao. Research on the relationship between bank credit and the conversion of new and old kinetic energy of manufacturing enterprises [D]. Lanzhou University, (2020).

2. Jie Guifeng. How can green credit drive the development of green economy_-Taking Binzhou City as an example [J]. Contemporary Financiers, 12 (2019).

3. Zhang Fangli, Kong Xiangfen, Zhou Fengying. Research on the reform path of green finance to support the conversion of new and old kinetic energy in Shandong [J]. Shanxi Agricultural Economics, 14 (2019).

4. Liu Yang. Research on Green Finance to Support the Conversion of New and Old Kinetic Energy in Shandong Province [J]. Shangxun, 21 (2019).

5. Liu Ying. Comprehensive evaluation of the development of green finance in Shandong Province [J]. Financial Development Research, 07 (2019).

6. Cao Jian. Research on financial policy support for Shandong's strategic emerging industries under the background of the conversion of new and old kinetic energy [D]. Qingdao University, (2019).

7. Liu Wen. Research on DG Bank Credit Risk Control under the Background of the Conversion of New and Old Kinetic Energy [D]. Shandong University, (2019).

8. Xu Rufeng, Gu Zhongrui. The credit dilemma of small and micro enterprises under the background of the conversion of new and old kinetic energy: based on the investigation and analysis of 432 samples in Shandong Province [J]. Hainan Finance, 05 (2019).

9. Shao Lin, Du Yinyou. Research on the financial support path of the transformation and upgrading of Shandong's manufacturing industry under the conversion of new and old kinetic energy [J]. Journal of Shandong Radio \& TV University, 02 (2019).

10. Yu Xiaohong. Exploration of the problem of the conversion of old and new kinetic energy supported by the banking industry [J]. Modern Marketing (Late Period), 03(2019).

11. Qin Changcai. The connotation and function of financial system support in the conversion of new and old kinetic energy [J]. Gansu Social Sciences, 01 (2019).

12. Wang Xiao. Broadly improve financial innovation and service capabilities to promote the conversion of new and old kinetic energy [J]. Village Rong Research, 04(2018). 